Maciej MuskaŁa

ORCID 0000-0002-5707-9149

Uniwersytet im. Adama Mickiewicza

$w$ Poznaniu

\title{
O ZNACZENIU WIĘZI SPOŁECZNYCH W PROCESIE RESOCJALIZACJI
}

\begin{abstract}
AвSTRACt. Muskała Maciej, O znaczeniu więzi społecznych w procesie resocjalizacji [About the Importance of Family Ties in the Process of Social Rehabilitation]. Studia Edukacyjne nr 52, 2019, Poznań 2019, pp. 107-125. Adam Mickiewicz University Press. ISSN 1233-6688. DOI: 10.14746/se.2019.52.8

In this article the author analyzes the significance of social bonds in the process of social rehabilitation. The present analysis focuses on three main areas in which "accumulation of social ties" takes place, as a result of which a violation of the law may take place. First of all, marriage (family), good work and, depending on the author of the study, hobbies and interests, military service and education are mentioned. The text ends with the presentation of models showing the relationship between individual predispositions (internal factors) and life events (external factors) in the process of moving away from crime.
\end{abstract}

Key words: social bond, social rehabilitation, family

Istniejąca znaczna heterogeniczność we wzorach przestępczości będzie rzutowała nie tylko na przebieg czy przyczyny procesu resocjalizacji, ale również na samą jego konceptualizację. Kariery przestępcze charakteryzują się pewnym stopniem niejednorodności/nieciągłości w toku życia, co już pół wieku temu D. Glaser opisał jako „zygzakowatą drogę" pomiędzy przestępczością a nieprzestępczością.

Przestępcy przechodzą od nieprzestępczości do przestępczości i znowu do nieprzestępczości. Czasami ta sekwencja powtarzana jest wiele razy, ale czasami przestępcy wchodzą w przestępczość tylko raz; czasami te zmiany są na długi okres, nawet na stałe, a czasami są krótkotrwałe ${ }^{1}$.

${ }^{1}$ D. Glaser, The Effectiveness of a Prison and Parole System, Indianapolis 1969, s. 58, za: J.H. Laub, R.J. Sampson, Understanding Desistance from Crime, Crime and Justice, 2001, 28, s. 54. 
Powyższe twierdzenie ma niebagatelne znaczenie dla właściwego rozumienia procesu zmiany przestępcy w byłego przestępcę, choćby przez fakt występowania różnych form niestabilności przestępczości. Jedna forma nieregularności ma miejsce wtedy, kiedy przestępca przez dłuższy okres „powstrzymuje się", „robi sobie przerwę" od zachowań naruszających porządek normatywny. Druga zaś pojawia się w sytuacji nieukończenia czy przerwania próby modyfikacji zachowań. W tym wypadku chęć do dokonania długotrwałej zmiany jest obecna $\mathrm{w}$ życiu osoby, ale nie jest w pełni zrealizowana ${ }^{2}$.

Istotna w tym kontekście jawi się kwestia więzi społecznych, owej nieformalnej kontroli społecznej czy "haków do zmiany”, konceptualizowanych przez A. Bottomsa i J. Shapland właśnie jako (zmieniający się) kapitał społeczny osoby ${ }^{3}$. Na ile i czy w ogóle ich obecność jest elementem koniecznym, a być może wystarczającym do pomyślnej zmiany trajektorii życiowych. Zgodnie $\mathrm{z}$ tą teorią, dość wpływową i rozpowszechnioną $\mathrm{w}$ literaturze przedmiotu, zmiana następuje stopniowo, $\mathrm{w}$ wyniku nagromadzenia więzi społecznych i zmieniających się społecznych asocjacji ${ }^{4}$, będących częściowo wynikiem racjonalnych decyzji lub osobistych upodobań, częściowo zaś uwarunkowanych stricte zewnętrznie.

Analizy koncentrują się na trzech głównych obszarach, w których dochodzi do "nagromadzenia więzi społecznych", wskutek czego ma lub może nastąpić zaniechanie działań naruszających prawo. W pierwszej kolejności wymienia się małżeństwo (rodzinę), dobrą pracę oraz, zależnie od autora opracowania, hobby i zainteresowania, służbę wojskową i wykształcenie. Szczególnie mocno J.H. Laub i R.J. Sampson w swoich publikacjach akcentują pogląd, że owe "punkty zwrotne" w cyklu życia są niezbędne dla zrozumienia procesów zmiany w przestępczej aktywności. Punkty zwrotne służą jako katalizatory zachowania długofalowej zmiany behawioralnej ${ }^{5}$ poprzez pozwolenie jednostkom, aby „odcięły teraźniejszość od przeszłości”, dostarczając możliwości wsparcia społecznego i przywiązania oraz zrutynizowanych struktur, co może wywołać zmiany w relacjach osoby ze społeczeństwem, a zatem $\mathrm{w}$ jej zaangażowaniu w przestępczość

${ }^{2}$ Ch. Carlsson, Processes of Intermittency in Criminal Careers: Notes from a Swedish Study on Life Courses and Crime, International Journal of Offender Therapy and Comparative Criminology, 2013, 57(8), s. 936.

3 A. Bottoms, J. Shapland, Steps towards desistance among male young adult recidivists, [w:] Escape Routes: Contemporary Perspectives on Life after Punishment, red. S. Farrall, M. Hough, S. Maruna, R. Sparks, Abingdon 2011, s. 43-80.

${ }^{4}$ L. Kazemian, S. Maruna, Desistance from Crime, [w:] Handbook on Crime and Deviance, red. M.D. Krohn, A.J. Lizotte, G.P. Hall, Springer 2009, s. 280.

${ }^{5}$ J.H. Laub, R.J. Sampson, Shared Beginnings, Divergent Lives: Delinquent Boys to Age 70, Cambridge - Massachusetts - London 2003, s. 149.

${ }^{6}$ Tamże, s. 148-149. 
Rutynowe czynności ${ }^{7}$ związane z pracą i życiem rodzinnym, poprzez które osoba zyskuje poczucie bezpieczeństwa i dobrego samopoczucia, oraz będące ich wynikiem nieformalne więzi społeczne, pełnią dwie funkcje. Jedną $\mathrm{z}$ nich jest zapewnienie społecznego wsparcia lub emocjonalnego „przywiązania". Druga funkcja to monitorowanie i kontrola poprzez zestaw czynności i zobowiązań, które często są powtarzane każdego dnia. Wiele nawyków jest prozaicznych, ale mimo to tworzą one strukturę czyjegoś czasu i ograniczają sposobności do przestępczości ${ }^{8}$.

Trzeba jednak zaznaczyć, że J.H. Laub i R.J. Sampson nie podchodzą do punktów zwrotnych i czynności rutynowych w sposób bezkrytyczny. Nie przypisują im jednoznacznie deterministycznego znaczenia, co dobrze oddaje przywołane przez nich stanowisko M. Ruttera, który ostrzega, że punkty zwrotne nie powinny być utożsamiane z najważniejszymi życiowymi doświadczeniami czy przypuszczalnymi transformacjami. Po pierwsze, niektóre transformacje nie prowadzą do zmiany trajektorii życia. Po drugie, niektóre transformacje raczej akcentują istniejące wcześniej cechy, niż wspierają zmianę. Pomimo tych trudności M. Rutter stwierdza, że „istnieją przekonujące dowody" na efekty punktów zwrotnych, zdefiniowane jako zmiana obejmująca "trwały zwrot kierunku trajektorii życia" ${ }^{9}$.

P.G. Giordano, S.A. Cernkovich i J.L. Rudolph dostrzegają kolejne trudności interpretacyjne, podkreślając, że związek małżeński oraz stabilna praca wywierają znaczny wpływ na zmianę zachowania, jeśli pojawią się równocześnie, tworząc tak zwany zestaw poważania (respectability package) ${ }^{10}$. W tym kontekście punkty zwrotne są od siebie zależne. Jeszcze dalej postępuje S. Maruna, podkreślając, że wartość idei punktów zwrotnych dla zrozumienia odstąpienia od przestępczości „została prawdopodobnie zawyżona”, ponieważ „nic takiego w sytuacji nie sprawia, że jest ona punktem zwrotnym”11. Dla tego autora bardziej obiecującą strategią jest skoncentrowanie się na jednostkach jako podmiotach własnej zmiany.

Już S. i E. Glueckowie zaobserwowali pozytywny wpływ małżeństwa na zachowania przestępcze. Późniejsze badania generalnie tylko potwierdzały

\footnotetext{
7 A. Giddens definiuje „rutynowe praktyki” jako podstawę tego, co większość ludzi robi przez większość czasu, A. Giddens, Stanowienie społeczeństwa. Zarys teorii strukturacji, Poznań 2003, s. 101.

${ }^{8}$ J.H. Laub, R.J. Sampson, Understanding Desistance from Crime, Chicago 2001, s. 48 i n.

${ }_{9}^{9}$ M. Rutter, Transitions and Turning Points in Developmental Psychopathology: As Applied to the Age Span Between Childhood and Mid-Adulthood, International Journal of Behavioral Development, 1996, 19(3), s. 621, za: J.H. Laub, R.J. Sampson, Shared Beginnings, Divergent Lives, s. 40.

${ }^{10}$ P.C. Giordano, S.A. Cernkovich, J.L. Rudolph, Gender, Crime, and Desistance: Toward a Theory of Cognitive Transformation, American Journal of Sociology, 2002, 107(4), s. 1013.

${ }_{11}$ S. Maruna, Making Good: How Ex-Convicts Reform and Rebuild Their Lives, Washington 2001, s. 42-43.
} 
tę tezę. Wskazywano między innymi na takie źródła zmiany w ekspozycji na przestępczość jak: zmiana stylu życia, szczególnie w odniesieniu do uczestnictwa $\mathrm{w}$ dewiacyjnych grupach rówieśniczych. Jak twierdzą D.W. Osgood i H. Lee ${ }^{12}$, małżeństwo pociąga za sobą zobowiązania, które mają tendencję do zmniejszenia ekspozycji na kryminalnych rówieśników. Małżeństwo w związ$\mathrm{ku} \mathrm{z}$ tym ma potencjał do odcięcia byłego przestępcy od jego przestępczej grupy rówieśniczej. N. Shover ${ }^{13}$ stwierdza, że „skuteczne ustanowienie więzi z bliskimi osobami i udział w konwencjonalnych czynnościach są głównymi warunkami na drodze prowadzącej do zakończenia przestępczej kariery"14; zastosowanie "lekarstwa geograficznego", zmiana miejsca zamieszkania. To fizyczne przemieszczenie prowadzi do zerwania wszelkich dotychczasowych więzi z dewiacyjnym środowiskiem, odcięcia się, czy wręcz izolacji od destrukcyjnych wpływów w nim występujących, co chroni jednostkę przed wystawianiem się na czynniki ryzyka; wzrost bezpośredniej społecznej kontroli stosowanej przez współmałżonka (dotyczy to głównie kobiet, o czym w dalszej części opracowania); zmiana tożsamości czy poczucia ,ja”. Jak zauważają J.H. Laub i R.J. Sampson, „Dla niektórych ożenienie się oznacza "spoważnienie”; innymi słowy, stanie się dorosłym. (...) Małżeństwo również oznaczało, że trzeba się kimś opiekować, i że ktoś opiekuje się tobą"15.

Najbardziej wyraziste stwierdzenie popierające tę linię rozumowania przedstawił N. Shover: „Ustanowienie wzajemnie satysfakcjonującej relacji z kobietą było powszechnym wzorcem (...) oraz ważnym czynnikiem przemiany ich przestępczego działania"16.

Nie wszyscy jednak akceptują powyższe spostrzeżenia. Niektórzy badacze, wśród których na poczesnym miejscu znajdują się M.R. Gottfredson i T. Hirschi ${ }^{17}$, twierdzą, że małżeńskie więzi nie zdarzają się tak po prostu, ale są tworzone przez indywidualny wybór, co czyni związek małżeństwo-przestępczość nie tak oczywisty.

D.P. Farrington i D.J. West stawiają wręcz pytanie, w jakim stopniu małżeństwo może być przyczyną, konsekwencją, czy symptomem zmiany i rezygnacji z przestępczego stylu życia. Sami stawiają tezę, że w pewnym wieku

${ }^{12}$ D.W. Osgood, H. Lee, Leisure Activities, Age, and Adult Roles across the Lifespan, Society and Leisure, 1993, 16(1), s. 181-208.

${ }^{13}$ N. Shover, Great Pretenders: Pursuits and Careers of Persistent Thieves, Boulder 1996, s. 126.

${ }^{14}$ Tamże za: J.H. Laub, R.J. Sampson, Shared Beginnings, s. 42.

${ }^{15}$ J.H. Laub, R.J. Sampson, Shared Beginnings, s. 43.

${ }^{16}$ N. Shover, The Later Stages of Ordinary Property Offender Careers, Social Problems, 1983, 31(2), s. 213, za: S. Farrall, A. Calverley, Understanding Desistance from Crime: Emerging Theoretical Directions in Resettlement and Rehabilitation, New York 2006, s. 6.

17 M.R. Gottfredson, T. Hirschi, A General Theory of Crime, Stanford 1990, za: R.J. Sampson, J.H. Laub, Desistance from Crime over the Life Course, [w:] Desistance from Crime over the Life Course, red. J. Mortimer, M.J. Shanahan, Springer 2004. 
nie ma ono wpływu na przestępczość, ale wytrwanie w nim - tak. Małżeństwo samo w sobie nie jest wystarczające, aby powstrzymać przestępczość, a jego efekt może być uzależniony od „powodów ślubu (np. ciąża), szczęścia w małżeństwie i tego, w jakim stopniu żona jest konwencjonalna i prospołeczna”18. Autorzy wyciągnęli wniosek, że „Małżeństwo ma raczej efekt skumulowany niż ostro wyznaczony"19.

Podobne stanowisko co do znaczenia czasu i jakości małżeństwa w procesie odchodzenia od przestępczości reprezentują J.H. Laub i R.J. Sampson. Na podstawie swoich obszernych badań sformułowali kilka tez oddających charakter relacji pomiędzy zawarciem związku małżeńskiego a odstąpieniem od przestępczości. Po pierwsze, zmiana zachowań przestępczych nie musi wynikać jedynie z małżeństwa. Może ona raczej wystąpić w odpowiedzi na trwałe przywiązanie, które pojawia się wraz z zawarciem małżeństwa. Z tego punktu widzenia rozwój więzi społecznych jest interpretowany jako proces inwestycyjny: im więcej jednostka inwestuje w więzi społeczne (małżeństwo), tym mniej prawdopodobne jest jej zaangażowanie się $\mathrm{w}$ działalność przestępczą, ponieważ ma więcej do stracenia. Efekt dobrego małżeństwa wymaga czasu na zaistnienie i rośnie powoli, stopniowo hamując przestępczość. Małżeństwo często prowadzi również do istotnych zmian w codziennych czynnościach rutynowych, szczególnie w odniesieniu do grup rówieśniczych. Jak zauważają autorzy, pociąga ono za sobą zobowiązania, które mają tendencję do zmniejszenia spędzania wolnego czasu poza rodziną. „Należy przyjąć, że małżonkowie będą spędzać więcej czasu razem (...) następuje spadek czasu spędzanego z przyjaciółmi i spadek ekspozycji na kryminalnych rówieśników" ${ }^{20}$. Może to być związane także zarówno z posiadaniem nowych znajomych i rodziny, jak też z faktem zmiany miejsca zamieszkania. Małżeństwo może też prowadzić do zmiany z powodu bezpośredniej społecznej kontroli stosowanej przez współmałżonka. Wreszcie, może zmienić czyjeś poczucie „ja” ${ }^{21}$.

Podsumowując, można stwierdzić, że to, co jest ważne w kategoriach ułatwiania zmiany zachowania przestępczego, to nie samo małżeństwo, ale raczej jakość związku. Jakościowo dobre małżeństwo może stanowić punkt zwrotny dla niektórych mężczyzn ze względu na samo wydarzenie, ich subiektywny stan, zachowanie innych oraz następujące po sobie zdarzenia wynikające $\mathrm{z}$ faktu, że są teraz żonaci ${ }^{22}$.

${ }^{18}$ D.P. Farrington, D.J. West, Effects of Marriage, Separation, and Children on Offending by Adults Males, [w:] Current Perspectives on Aging and the Life Cycle, red. Z.S. Blau, J. Hagan, vol. 4, Greenwich Conn. 1995, s. 278, za: J.H. Laub, R.J. Sampson, Shared Beginnings, Divergent Lives, s. 281.

19 Tamże.

${ }^{20}$ J.H. Laub, R.J. Sampson, Shared Beginnings, Divergent Lives, s. 42.

${ }^{21}$ Tamże, s. 41-44.

22 Tamże, s. 281. 
Pomimo dowodów na to, że stworzenie związku „może” spowodować zmianę zachowania na wolne od naruszania porządku normatywnego, niektórzy badacze zakwestionowali ten raczej prosty model przyczynowo-skutkowy $^{23}$. Jak zauważają M.R. Gottfredson i T. Hirschi, żony, domy i dzieci „brzmią miło" jako wyjaśnienie, ale "nie wydają się mieć wpływu na prawdopodobieństwo przestępczości”. Przeglądając badania nad „kojarzeniem selektywnym", autorzy ci wyciągają wniosek, że przestępca zwykle przekształca takie instytucje (małżeństwo, praca) w źródła satysfakcji zgodne z jego poprzednim przestępczym zachowaniem ${ }^{24}$.

Podobnie jak w przypadku małżeństwa, praca, wykształcenie, czy inne kluczowe wydarzenia życiowe, które powodują rozwój więzi społecznych, korelują z odchodzeniem od przestępczego stylu życia, ale niekoniecznie będą jego czynnikami sprawczymi. Chociaż w literaturze znajdują się liczne opracowania potwierdzające tezę, że zatrudnienie może redukować prawdopodobieństwo recydywy, a brak zatrudnienia niekoniecznie musi wiązać się ze wzrostem popełniania przestępstw ${ }^{25}$, to równie bogato reprezentowana jest literatura przecząca temu twierdzeniu. M.R. Gottfredson i T. Hirschi wykazali, że różnice we wskaźnikach przestępczości wśród pracujących i bezrobotnych są niewielkie lub w ogóle nie występują, a nawet jeśli się pojawiają, to mają charakter przeciwny do oczekiwanego ${ }^{26}$. Natomiast tacy autorzy, jak J. Ditton czy S. Henry wykazali, że zatrudnienie na pełen etat nie wyklucza przestępczości ${ }^{27}$. Zatrudnienie zatem może, choć nie musi, redukować prawdopodobieństwo popełniania przestępstw, a jego brak niekoniecznie musi wiązać się ze wzrostem tego typu zachowań.

J.H. Laub i R.J. Sampson twierdzą, że procesy leżące u podstaw zależności między pracą a odchodzeniem od przestępczości są podobne do występujących w przypadku małżeństwa i sprowadzają się do czterech głównych czynników. Pierwszym jest wzajemna wymiana kapitału społecznego: inwestycja ze strony pracodawców może wywołać zwrotną inwestycję w kapitał społeczny ze strony pracowników. Zgodnie z założeniem teoretycznym ta

${ }^{23}$ S. Farrall, A. Calverley, Understanding Desistance from Crime, s. 5, i cytowana tam literatura.

${ }^{24}$ M.R. Gottfredson, T. Hirschi, A General Theory of Crime, Stanford 1990, s. 140-141, za: R.J. Sampson, J.H. Laub, Desistance from Crime.

${ }^{25}$ F. McNeill, B. Weaver, Changing Lives? Desistance Research and Offender Management, The Scottish Centre for Crime and Justice Research, Report No.03/2010, s. 56, i cytowana tam literatura.

${ }^{26}$ M.R. Gottfredson, T. Hirschi, A General Theory of Crime, Stanford 1990, za: R.J. Sampson, J.H. Laub, Desistance from Crime, s. 138-139.

${ }_{27}$ J. Ditton, Part-Time Crime: An Ethnography of Fiddling and Pilferage, London 1977; S. Henry, The Hidden Economy: The Context and Control of Borderline Crime, Oxford 1978, za: S. Farrall, B. Bowling, Structuration, Human Development and Desistance from Crime, British Journal of Criminology, 1999, 39(2), s. 259. 
współzależność jest obopólna i osadzona w więzach społecznych pomiędzy jednostkami a instytucjami społecznymi ${ }^{28}$. Drugi czynnik, to już podkreślana przez J.H. Lauba i R.J. Sampsona, rola czynności rutynowych. Twierdzą oni, że „praca - nawet bardziej niż małżeństwo - szczególnie w pełnym wymiarze godzin prowadzi do znaczących zmian w rutynowych czynnościach"29. Jako trzeci element autorzy ci wskazują, że pracodawcy mogą stanowić bezpośrednią nieformalną kontrolę społeczną, zaś jako czwarty, że „praca może dać człowiekowi poczucie tożsamości i sens życia" ${ }^{30}$.

Podsumowując te rozważania, można stwierdzić, że związek pomiędzy więzami społecznymi a odstąpieniem od przestępczości ma niejednoznaczny charakter. Niektóre badania potwierdzają, inne kwestionują tę zależność. Taki stan rzeczy może wynikać zarówno z błędnych założeń teoretycznych co do samej możliwości wpływania na proces odchodzenia od przestępczości poprzez charakter więzi społecznych, jak i - tylko (sic!) - uchybień metodologicznych. Istnieje jednak jeszcze inna próba interpretacji, zgodnie z którą te zróżnicowania czy niejednoznaczności mogą wynikać z cech samej jednostki. Poszczególne osoby bardzo się różnią w sposobach reakcji na bodźce społeczne. To samo wydarzenie może wywierać różny wpływ zależnie od płci, wieku, wcześniejszych doświadczeń, czy cech osobowości. Badania sugerują na przykład, że kobiety porzucają przestępstwo szybciej niż mężczyźni. Opuszczenie domu i tworzenie nowej rodziny były dla nich wysoce skorelowane $z$ porzuceniem przestępczego stylu życia. Jednak w przypadku młodych mężczyzn takie zmiany społeczne miały mały wpływ na wzorce przestępczości.

Na silne zróżnicowanie płciowe zwracają uwagę J.H. Laub i R.J. Sampson w odniesieniu do znaczenia zawierania związków małżeńskich na proces odstąpienia. Autorzy pokazują w swojej sztandarowej pracy, że mężczyźni zazwyczaj wiążą się z partnerkami, które reprezentują pewien poziom kontrastu w stosunku do ich orientacji i stylu życia, podnosząc swój status (marry 'up'), w przeciwieństwie do kobiet, które zwykle obniżają go (marry 'down') ${ }^{31}$. Podobne stanowisko przedstawia M. Rotter: „Małżeństwo jako takie nie ma bardzo przewidywalnego efektu. To wszystko zależy od osoby, którą się poślubia, kiedy się ją poślubia oraz rodzaju osiągniętych relacji”32.

Najistotniejsze jednak $w$ tym względzie wydaje się ustalenie sugerowane między innymi przez C. Uggena ${ }^{33}$, że wpływ różnych wydarzeń życio-

${ }^{28}$ J.H. Laub, R.J. Sampson, Shared Beginnings, Divergent Lives, s. 46.

29 Tamże, s. 47.

${ }^{30}$ Tamże.

${ }^{31}$ Tamże, s. 45-46.

${ }^{32}$ M. Rutter, Transitions and Turning Points in Developmental Psychopathology: As Applied to the Age Span Between Childhood and Mid-Adulthood, Journal of Behavioral Development, 1996, 19(3), s. 610, za: S. Maruna, Making Good, s. 31-32.

${ }_{33}$ C. Uggen, Work as a Turning Point in the Life Course of Criminals: A Duration Model of Age, Employment, and Recidivism, American Sociological Review, 2000, 65(1), s. 542. 
wych na przestępczość jest stopniowany ze względu na wiek. Ustalenie to ma szczególne znaczenie $\mathrm{w}$ kontekście działań podejmowanych przez wymiar sprawiedliwości oraz system resocjalizacji. Można tu mówić o korelacji między odstąpieniem a wiekiem ${ }^{34}$, czy też o swoistym oknie szans bądź możliwości (window of opportunity).

Zmiany rozwojowe są wszak związane zarówno z procesami biologicznymi, jak i społecznymi, a dokonują się na przykład zgodnie z koncepcją zadań rozwojowych R.J. Havighursta, który odnosi je do zbioru sprawności i kompetencji motorycznych, poznawczych, emocjonalnych i społecznych, nabywanych przez jednostkę $\mathrm{w}$ trakcie jej kontaktów $\mathrm{z}$ otoczeniem, a powodzenie w realizowaniu zadań w okresach późniejszych zależy od tego, jak jednostka poradziła sobie z zadaniami wcześniejszymi.

Treść zadań rozwojowych, przed jakimi staje ona w kolejnych okresach swego życia, wiąże się z tym, jakim przemianom podlega wewnętrzne środowisko jej rozwoju (organizm - obszar psyche), jakim przemianom podlega jej otoczenie czy środowisko zewnętrzne (głównie relacje społeczne - obszar polis), a także z tym, z jakimi kompetencjami opuściła poprzednie etapy rozwoju i jakie są jej aktualne zasoby związane z radzeniem sobie w różnych sytuacjach życiowych (obszar zasobów intelektualnych, emocjonalnych i społecznych oraz poziom świadomości ich posiadania - obszar psyche) $)^{35}$.

Nie oznacza to, że podejmowanie jakichkolwiek działań wobec osób niedostosowanych społecznie jest bezzasadne. Już S. i E. Glueckowie przyjmują taką możliwość kiedy pytają: „Czy pedagodzy, psycholodzy, pracownicy resocjalizacyjni i inni mogą opracować takie środki ‘zmuszenia rośliny', żeby łagodne dojrzewanie nastąpiło wcześniej, niż wydaje się być obecnie?"36. Jest to możliwe nie dlatego, że działania te mają za zadanie przyspieszyć „dojrzewanie rośliny”, ale raczej nadgonić utracony czas. Jakość życia i płynne, bezkonfliktowe przechodzenie do kolejnych etapów rozwojowych zależy od stopnia zsynchronizowania obu zegarów: biologicznego i społecznego, to znaczy dostosowania zadań stawianych przez społeczeństwo do możliwości organi$\mathrm{zmu}^{37}$, ale także od punktualności doświadczeń życiowych, „zgodności lub niezgodności z zegarem społecznym, co oznacza, że zmiana rozwojowa jest dostrzegana nie tylko na poziomie biologicznym i społecznym, lecz także na

${ }^{34}$ Por. tabela $8 \mathrm{w}$ tekście R. Loeber et al., Initiation, Escalation and Desistance in Juvenile Offending and Their Correlates, Journal of Criminal Law and Criminology, 1991, 82(1), s. 42.

35 A. Brzezińska, Społeczna psychologia rozwoju, Warszawa 2000, s. 228.

36 S. Glueck, E. Glueck, Later Criminal Careers, New York 1937, s. 205, za: L. Kazemian, S. Maruna, Desistance.

${ }^{37}$ J. Wojciechowska, Okres wczesnej dorostości. Jak rozpoznać ryzyko i jak pomagać? [w:] Psychologiczne portrety człowieka. Praktyczna psychologia rozwojowa, red. A.I. Brzezińska, Gdańsk 2005, s. 474 . 
poziomie psychicznym" ${ }^{38}$. W przypadku osób niedostosowanych społecznie dochodzi zazwyczaj do późniejszego niż u ich rówieśników podejmowania zadań rozwojowych i rozwoju poczucia niepunktualności zdarzeń życiowych w stosunku do odczuwanego braku gotowości, co może prowadzić do rozwoju tożsamości moratoryjnej czy rozproszonej ${ }^{39}$.

Na przykład, przywołany kilka akapitów wcześniej C. Uggen stwierdził, że efekt zapewnienia minimalnych możliwości zatrudnienia byłym przestępcom był zależny od wieku. W przy padku osób powyżej 26 lat praca może być, jak się wydaje, punktem zwrotnym w przestępczej karierze, podczas gdy ma ona marginalny wpływ na przestępczość młodszych przestępców. Autor ten zauważa, że znaczenie pracy i przestępczości może się zmienić, kiedy jednostka przechodzi z okresu dojrzewania w dorosłość, co wskazuje na to, że desistance ma również subiektywny element, który należy zrozumieć ${ }^{40}$. W podobnym duchu wypowiadają się M. Ouimet i M. Le Blanc, stwierdzając, że w ich grupie badawczej związek z kobietą łączył się z porzuceniem zachowań przestępczych w przypadku mężczyzn w wieku około 25 lat ${ }^{41}$.

Niewątpliwie, kolejnym zagadnieniem, na jakie należy zwrócić uwagę przy badaniu zależności pomiędzy społecznymi uwarunkowaniami a odstąpieniem od przestępczości, jest fakt - jak zauważa L. Kazemian - powszechnie pomijany we współczesnych opracowaniach, zmieniającej się struktury i kształtu więzi społecznych w dzisiejszym społeczeństwie ${ }^{42}$. Na przykład, nieuwzględnianie wzrostu znaczenia związków partnerskich (konkubinatu) czy tendencji do wchodzenia $\mathrm{w}$ związek małżeński w późniejszym wieku może deprecjonować osiągane wyniki świadczące o znaczeniu małżeństwa w hamowaniu kariery przestępczej. Również mechanizmy konkurencji na rynku pracy przyczyniły się do zwiększenia poziomu wykształcenia w społeczeństwie, co skutkuje późniejszą penetracją tegoż rynku pracy. W tym kontekście niektóre wskaźniki więzi społecznych mierzone w okresie późnej adolescencji i wczesnej dorosłości, takie jak poziom zaangażowania w pracę zawodową i bliskość ze współpracownikami oraz przełożonymi, nie wydają się tak znaczące, jak to miało miejsce jeszcze kilkadziesiąt lat temu ${ }^{43}$.

38 Tamże.

39 Zob. A. Brzezińska, Dzieciństwo i dorastanie: korzenie tożsamości osobistej i społecznej, [w:] Edukacja regionalna, red. A. Brzezińska, A. Hulewska, J. Słomska, Warszawa 2006, s. 47-77.

40 C. Uggen, Work as a Turning Point in the Life Course of Criminals: A Duration Model of Age, Employment, and Recidivism, American Sociological Review, 2000, 65(1), s. 542.

${ }_{41}$ M. Ouimet, M. Le Blanc, The Role of Life Experiences in the Continuation of the Adult Criminal Career, Criminal Behaviour and Mental Health, 1996, 6(1), s. 92, za: S. Farrall, A. Calverley, Understanding Desistance from Crime.

42 Por. J. Savolainen, Work, Family and Criminal Desistance: Adult Social Bonds in a Nordic Welfare State, British Journal of Criminology, 2009, 49(3), s. 285-304.

${ }^{43}$ L. Kazemian, Desistance from Crime: Theoretical, Empirical, Methodological, and Policy Considerations, Journal of Contemporary Criminal Justice, 2007, 23(1), s. 16. 
Istotne staje się zatem zaadaptowanie mierników więzi społecznych do zmieniających się społecznych norm i wartości. Nieuwzględnienie tych przeobrażeń może doprowadzić do błędnej interpretacji ról pełnionych przez więzi społeczne $\mathrm{w}$ procesie odstąpienia od przestępczości. Trzeba jednak podkreślić, że zmienne te dostarczają niewiele informacji na temat, jak i dlaczego następuje zmiana, a jeszcze mniej o tym, w jaki sposób można ją zainicjować.

Mimo tych rozlicznych argumentów co do znaczenia i siły wpływu więzi społecznych na proces resocjalizacji stanowisko to spotyka się z licznymi uwagami krytycznymi.

Wydaje się, na co zwraca uwagę S. Maruna, że to, czego brakuje w tych podejściach to "osoba” - całość i podmiotowość jednostki. Różne osoby wystawione na to samo środowisko doświadczają go, interpretują i reagują na nie w odmienny sposób. Dlatego sugeruje się, że doświadczenia prowadzące do odstąpienia od przestępczości niekoniecznie mają charakter uniwersalny i często mogą w większym bądź mniejszym stopniu być pod kontrolą jednostki. Każda osoba wydobywa subiektywne, psychologiczne środowisko z obiektywnego otoczenia i to ono kształtuje zarówno osobowość, jak i kolejne interakcje ${ }^{44}$. I choć subiektywne aspekty ludzkiego życia (emocje, myśli, motywacje i cele) zostały $\mathrm{w}$ dużej mierze pominięte $\mathrm{w}$ badaniach przestępczości, ponieważ dane te uznawane są albo za nienaukowe, albo zbyt nieporęczne dla empirycznych analiz ${ }^{45}$, zaczyna wyłaniać się spójna grupa badań nad zmianą stylu życia z przestępczego na wolne od tego typu zachowań, jako procesem stopniowym i dynamicznym, który wynika z interakcji pomiędzy czynnikami wewnętrznymi i zewnętrznymi.

Zrozumienie przestępcy (a nie tylko przestępstwa, jak robi to większość teorii kryminologicznych) wymaga uzupełnienia obrazu o przegląd unikatowych osobistych historii.

Sposób, w jaki każdy z nas postrzega własną historię, jest interesujący nie tylko ze względu na to, co mówi o naszej osobowości i pochodzeniu; ta subiektywna autobiografia rzeczywiście kształtuje nasze przyszłe wybory i zachowania ${ }^{46}$.

Próba zrozumienia relacji pomiędzy jednostką, jej „wnętrzem” a strukturą i kulturą w odniesieniu do odstąpienia od przestępczości, skierowała za-

${ }^{44}$ A. Caspin, T.E. Moffit, The Continuity of Maladaptive Behavior: From Description to Understanding in the Study of Antisocial Behavior, [w:] Developmental Psycholopathology, vol. 2: Risk, disorder and adaptation, red. D. Cicchetti, D.J. Cohen, New York 1995, s. 485, za: S. Maruna, Making Good, s. 32-33.

${ }^{45}$ S. Maruna, Making Good, s. 8.

${ }^{46}$ S. Maruna, Desistance and Development: The Psychosocial Process of 'Going Straight', The British Criminology Conferences: Selected Proceedings, vol. 2. Papers from the British Criminology Conference, Queens University, Belfast, 15-19 July 1997, http:// britsoccrim.org/volume2/003.pdf, [dostęp: 26.07.2014], s. 5. 
interesowania wielu badaczy głównie na dorobek A. Giddensa i P. Bourdieu, w stronę socjologicznych teorii średniego zasięgu ${ }^{47}$. To wszak w teorii strukturacji A. Giddensa postrzeganie podmiotów i struktur jako oddzielnych uważane jest za zasadniczy błąd ${ }^{48}$. Ani podmiot, ani struktura tak naprawdę nie istnieją niezależnie od siebie.

Tworzenie (i ciągła re-kreacja) zarówno 'podmiotów', jak i 'struktur' następuje w tym samym momencie poprzez te same mechanizmy. Oba [elementy] są zaangażowane $\mathrm{w}$ reprodukcję siebie nawzajem ${ }^{49}$.

Podmioty i struktury nie są dwoma niezależnymi zestawami zjawisk, ale reprezentują dwoistość struktury. A. Giddens konceptualizuje struktury zarówno jako medium, jak i wynik zachowania jednostek. Właściwości strukturalne systemów społecznych są zatem środkiem i wynikiem warunkowo ukończonych działań podmiotów, nie istnieją poza działaniem, ale ciągle biorą udział w jego produkcji i reprodukcji.

Z punktu widzenia idei odstąpienia od przestępczości podkreśla się, że istnieją dwie pozytywne cechy podejścia A. Giddensa. Pierwszą jest jego silny nacisk na czynnik ludzki, podmiotowość. Osoba naprawdę ma wybór, nawet w dość ograniczonych czy beznadziejnych okolicznościach. Po drugie, poprzez podkreślenie, że struktury społeczne istnieją tylko dlatego, że ludzie je reprodukują, A. Giddens przypomina, iż w pewnych warunkach społecznych struktury w rzeczywistości nie będą utrzymane ${ }^{50}$.

Jednak, chociaż uwagi o współdziałaniu w procesie resocjalizacji pomiędzy indywidualnymi wyborami a szerszymi siłami społecznych, instytucjonalnych i społecznych praktyk, które są poza kontrolą jednostki, stały się powszechne, to charakter tego oddziaływania jest ciągle kwestionowany, zwłaszcza w kontekście roli, jaką odgrywa jednostka. J.H. Laub i R.J. Sampson na przykład, choć twierdzą w swojej analizie, że pełne wyjaśnienie musi obejmować zarówno czynniki strukturalne, jak i subiektywne, to jednak dowodzą, że odstąpienie od przestępczości dokonuje się niekoniecznie świadomie czy celowo, ale raczej „zaocznie” - jako wynik „ubocznego zakładu” („by default" - the result of ", side bets"). W podawanym przez nich przykładzie mężczyźni podjęli zobowiązanie, że wyjdą na prostą bez świadomości tego faktu.

47 Zob. S. Farrall, A. Bottoms, J. Shapland, Social Structures and Desistance from Crime, European Journal of Criminology, 2010, 7(6), s. 550-553; S. Farrall, B. Bowling, Structuration, Human Development and Desistance from Crime, British Journal of Criminology, 1999, 39(2), s. 254-255 i cytowana tam literatura; M. Muskała, Skazani na brak sukcesu? Reprodukcja wykluczenia społecznego w świetle koncepcji Pierre'a Bourdieu, [w:] Młodzież i sukces życiowy, red. D. Hildebrandt-Wypych, K. Kabacińska, Kraków 2010, s. 157-171.

48 A. Giddens, Stanowienie społeczeństwa.

49 S. Farrall, B. Bowling, Structuration, s. 255.

50 Tamże. 
Zanim zdali sobie $\mathrm{z}$ tego sprawę, zainwestowali tak dużo w małżeństwo czy pracę, że nie chcieli zmarnować swojej inwestycji. Ich zaangażowanie w owe instytucje - prace i małżeństwo przeobraża krótkoterminowe sytuacyjne zachęty do przestępstwa i z czasem kieruje na inny tor - długoterminowego zobowiązania do zgodności (konformizmu) ${ }^{51}$.

Dotychczasowe rozważania i próby ingerencji w te wewnętrzne czynniki realizowane $\mathrm{w}$ duchu modelu what works skupiają uwagę na kognitywnych transformacjach, których doświadczają przestępcy. Nauczanie przestępców umiejętności poznawczych nie musi mieć długoterminowego wpływu na recydywę, choć przynosi z pewnością znaczące efekty krótkotrwałe, i nie wydaje się redukować przestępczości w dłuższym czasie. Ta niezdolność do osiągnięcia długoterminowej „abstynencji od przestępczości” poprzez ukierunkowanie na subiektywną zmianę jest dodatkowo poparta ustaleniami programów zajmujących się subiektywną zmianą: wpływ terapii znika, kiedy uwzględnia się czynniki ryzyka lub po okresie dwóch lat. Sugeruje to, że zwracanie uwagi tylko na kognitywne i subiektywne doświadczenia może być niewystarczające, kiedy usiłuje się zrozumieć trwałą zmianę zachowania ${ }^{52}$. Oddziaływania na zmiany subiektywne są więc konieczne, lecz niewystarczające, bowiem kapitał ludzki trzeba mieć gdzie spożytkować.

Istotne i trwałe zmiany w zachowaniu przestępczym rzadko kiedy wypływają jako wynik pasywnego doświadczenia, a takie zmiany zostają najlepiej skonceptualizowane jako wynik procesu wymagającego znacznej partycypacji sprawcy, który to proces pod wieloma względami jawi się jako własny czynnik zmiany ${ }^{53}$.

Ostatnie badania dążące do integracji zrozumienia, w jaki sposób indywidualne predyspozycje (czynniki wewnętrzne) i zdarzenia życiowe (czynniki zewnętrzne) prowadzą do odstąpienia od przestępczości napotykają na niewyjaśnioną, a zwłaszcza z punktu widzenia praktyki niezwykle istotną kwestię relacji zachodzących pomiędzy czynnikami subiektywnymi a lepiej znanymi zmiennymi społecznymi w procesie zaniechania. Konkludując roz-

${ }^{51}$ J.H. Laub, R.J. Sampson, Understanding Desistance from Crime, Crime and Justice, 2001, 28 , s. 50-51. Należy jednak dla porządku dodać, iż w poprawionej wersji swojej teorii podkreślają, że "osobiste działania wyłaniają się w znacznym stopniu” w trajektoriach zaniechania i trwania w przestępczości oraz że „ludzie badani byli aktywnymi uczestnikami konstruowania swojego życia", zob. J.H. Laub, R.J. Sampson, Shared Beginnings, Divergent Lives, s. 280-281.

${ }^{52}$ K.G. Walker, E. Bowen, S. Brown, Examining the Psychological, Social and Subjective Dimensions Associated with Desistance from Offending: A Review of the Literature, 2011, http://works. bepress.com/kate_walker/1, [dostęp: 26.07.2014], s. 28.

${ }^{53}$ K. Adams, Developmental Aspects of Adult Crime, [w:] Advances in Criminological Theory, vol. 6: Developmental Theories of Crime and Delinquency, red. T.P. Thornberry, New Brunswick 1997, s. 334-335, za: T.P. LeBel et al., The 'Chicken and Egg' of Subjective and Social Factors in Desistance from Crime, European Journal of Criminology, 2008, 5(2), s. 135. 
ważania na ten temat, S. Farrall i B. Bowling zauważają, że w badaniach empirycznych traktowano jednostki albo jako "superpodmioty” (super agents), albo jako „super naiwniaków/ofiary” (super dupes)

W tym pierwszym modelu (silny model subiektywny) główny argument opiera się na założeniu, że liczy się przede wszystkim siła woli, motywacja. Jednostka musi zadecydować, by zmienić swoją tożsamość i spojrzenie na przyszłość w celu wyjścia na prostą. W ramach tego systemu zewnętrzne wydarzenia są albo całkowicie niezwiązane z sukcesem, albo też całkowicie skorelowane z subiektywnym oglądem. W pierwszym przypadku wyjście na prostą powiązane jest z innymi wydarzeniami życiowymi. Od kiedy jednostka zdecyduje się na zaniechanie przestępczości, czynniki społeczne takie jak bezrobocie tracą na znaczeniu. W drugim przypadku twierdzi się, że wydarzenia życiowe, które następują, są istotne, lecz pozostają w dużym stopniu pod kontrolą jednostki. Bardziej prawdopodobne jest, że jednostka, posiadając właściwy ogląd, wybierze wydarzenia inicjujące zmianę (jak np. małżeństwo, zatrudnienie lub rodzicielstwo). Bez tego apriorycznego oglądu wydarzenia te zapewne w ogóle by nie nastąpiły. W tym modelu wydarzenia same w sobie nie mają mocy przyczynowej, by zmieniać zachowanie ludzkie - są bardziej tym, co się wydarza, gdy zmotywowane jednostki decydują się na zmianę ${ }^{54}$.

W drugim przypadku (silny model społeczny) liczą się okoliczności społeczne w odniesieniu do tego, czy dana osoba zdolna jest do zaniechania przestępczości, czy też nie. Kluczowe momenty życiowe stanowione są przez zewnętrzne wydarzenia, które zachodzą (przynajmniej częściowo) przypadkowo. Co prawda, niektóre wydarzenia mogą być produktem świadomego wysiłku, jednak tym co liczy się najbardziej w przypadku zaniechania jest to, czy dobre rzeczy (np. dobre małżeństwo czy dobra praca) mają miejsce. To właśnie pojawienie się tego typu wydarzeń, pozostających w znacznym stopniu poza kontrolą jednostki, stanowi najlepszy czynnik pozwalający przewidzieć jej sukces po opuszczeniu więzienia. Z tego punktu widzenia subiektywny ogląd osób zwolnionych nie jest istotny dla wyjścia na prostą ${ }^{55}$.

Żaden z tych przeciwstawnych wniosków nie jest "zły", ale raczej stanowią one dwie strony tego samego medalu ${ }^{56}$. T.P. LeBel, R. Burnett, S. Maruna i S. Bushway wskazują na jeszcze jeden model wyjaśniający interakcje między społecznymi a subiektywnymi czynnikami prowadzącymi do odstąpienia od przestępczości - połączony model subiektywno-społeczny (interakcyjny) ${ }^{57}$.

\footnotetext{
${ }^{54}$ T.P. LeBel et al., The 'Chicken and Egg', s. 137.

55 Tamże, s. 139.

${ }^{56}$ S. Farral, B. Bowling, Structuration, s. 261.

57 T.P. LeBel et al., The 'Chicken and Egg'.
} 
Zakłada on, że zarówno subiektywne perspektywy, jak i wydarzenia społeczne mogą mieć wpływ na przebieg życia po wyjściu z zakładu karnego. Możliwe są tu dwie okoliczności. Po pierwsze, zarówno subiektywne perspektywy, jak i problemy społeczne mogą mieć niezależny wpływ na recydywę. W modelu tym subiektywne perspektywy liczą się, lecz nie determinują całkowicie recydywy, a wydarzenia życiowe (tj. problemy społeczne doświadczane po opuszczeniu więzienia) mają niezależny od nich wpływ na zachowanie. Model ten różni się od modelu silnie subiektywnego, ponieważ czynniki społeczne mogą mieć niezależny wpływ na wyniki, a także od modelu silnie społecznego, gdyż perspektywy subiektywne będą miały znaczenie wówczas, kiedy nie zostaną ujęte czynniki społeczne. Po drugie, perspektywa subiektywna może mieć pośredni wpływ na wyniki poprzez wydarzenia społeczne, które następują po niej. Na przykład, mentalność jednostki ma wpływ na jej większy upór w poszukiwaniu zatrudnienia z ewentualnymi pozytywnymi rezultatami. Lepsze wyniki w zatrudnieniu prowadzą dalej do mniejszego prawdopodobieństwa wystąpienia recydywy. W modelu tym wpływ czynników społecznych zależny jest od poziomu subiektywnych charakterystyk. Jeśli dana osoba ma odpowiedni subiektywny typ mentalności, może być zdolna do wykorzystywania dobrych wydarzeń życiowych, które ją spotykają, i nie zostanie zepchnięta z właściwego kursu przez klęski w sferze społecznej. Innymi słowy, subiektywna mentalność jest koniecznym, lecz niewystarczającym warunkiem do osiągnięcia sukcesu po zwolnieniu z więzienia. Pozytywne wydarzenia społeczne konieczne są, aby wspierać i zachęcać do zaniechania przestępczości ${ }^{58}$.

Autorzy próbowali empirycznie rozwikłać te trzy modele poprzez analizę danych z wielokrotnych wywiadów ze 130 recydywistami. Zmienne niezależne stosowane do zbadania subiektywnego sposobu myślenia obejmowały nadzieję, żal i wstyd, zinternalizowanie stygmatyzacji, alternatywne tożsamości i problemy społeczne. Wyniki doprowadziły autorów do wykluczenia silnego subiektywnego (super agents) i silnego społecznego (super dupes) modelu oraz do poparcia modelu subiektywno-społecznego. Ustalenia te sugerują, że $\mathrm{w}$ procesie odchodzenia od przestępczości różne czynniki zewnętrzne i wewnętrzne oddziałują w różny sposób. Z jednej strony badacze stwierdzili, że niektóre problemy społeczne zdawały się występować niezależnie, bez jakiegokolwiek związku z poglądami przestępcy (optymistycznymi lub pesymistycznymi). Z drugiej strony odkryli, że osoby, które przejawiają największe zaufanie do swoich możliwości zmiany, rzadziej są recydywistami. Jednostki, które nastawiły się na zmianę zachowania i miały wspierające sieci społeczne, były lepiej wyposażone, żeby stawić czoła problemom, oprzeć się pokusom

58 Tamże, s. 139-140. 
i uniknąć niepowodzeń. Jednak autorzy stwierdzili również, że chęć zmiany może być niewystarczająca, kiedy problemy społeczne są przytłaczające i nadmierne.

Ten potencjał sieci można rozpatrywać w coraz bardziej popularnej także na gruncie pedagogiki resocjalizacyjnej perspektywie resilience ${ }^{59}$. Również w przypadku resilience obserwuje się przesunięcie od stanowisk bardziej deterministycznych, charakterystycznego dla początkowych analiz, w kierun$\mathrm{ku}$ zrozumienia resilience jako procesu ${ }^{60}$. Kwestionuje się pogląd, że sama obecność czynników ochronnych w życiu dzieci i młodzieży wystarczy, żeby wyjaśnić prospołeczne wyniki w niesprzyjających okolicznościach. Podkreśla się aktywne wykorzystanie zasobów osiągalnych lub chęć zaangażowania się $\mathrm{w}$ procesy ochronne, co prowadzi J. Rumgaya do sugestii, że resilience powstaje raczej jako zaradność $\mathrm{w}$ pokonywaniu trudności niż jako niewrażliwość na trudności ${ }^{61}$.

Choć powyższe ustalenia dotyczące interakcji między społecznymi a subiektywnymi czynnikami towarzyszącymi odchodzeniu od przestępczości zostały potwierdzone $\mathrm{w}$ innych opracowaniach, to jednak charakter tego oddziaływania jest ciągle kwestionowany, zwłaszcza przez rolę, jaką odgrywa jednostka. Można tu przywołać przytoczone wcześniej uwagi J.H. Laubaa i R.J. Sampsona, że zmiana stylu życia z przestępczego na wolny od tego typu zachowań dokonuje się pośrednio i nieświadomie, raczej jako wynik „ubocznych inwestycji” w zatrudnienie i związki partnerskie niż poprzez kognitywne transformacje czy zmiany tożsamości, albo też uwagę P. Giordana i współpracowników, którzy mimo generalnej akceptacji poznawczego modelu odstąpienia od przestępczości bardzo silnie podkreślają znaczenie środowiska społecznego, choćby w takim zdaniu:

Biorąc pod uwagę stosunkowo „korzystny” zestaw zbiegów okoliczności, poznawcze transformacje, które opisujemy, nie są wcale konieczne; w warunkach dostatecznie ekstremalnej niekorzystnej sytuacji są one mało prawdopodobne ${ }^{62}$.

${ }^{59} \mathrm{Na}$ temat pojęcia resilience oraz wykorzystania tej perspektywy w pedagogice resocjalizacyjnej zob. W. Pilecka, J. Fryt, Teoria dziecięcej odporności psychicznej, [w:] Psychologia zdrowia dzieci i młodzieży. Perspektywa kliniczna, red. W. Pilecka, Kraków 2011, s. 48 i n.; B. Urban, Zaburzenia w zachowaniu; tenże, Kognitywno-interakcyjne podstawy wspótczesnej resocjalizacji, [w:] Resocjalizacja, ciagłość i zmiana, red. M. Konopczyński, B. Nowak, Warszawa 2008, s. 28-38; tenże, Agresja młodzieży i odrzucenie rówieśnicze, Warszawa 2012, rozdział V, zwłaszcza s. 148-165.

${ }^{60}$ C. Murray, Conceptualizing Young People's Strategies of Resistance to Offending as 'Active Resilience', British Journal of Social Work, 2010, 40(1), s. 117.

${ }^{61}$ J. Rumgay, Scripts for Safer Survival: Pathways Out of Female Crime, The Howard Journal of Criminal Justice, 2004, vol. 43(4), s. 412, za: C. Fitzpatrick, What is Difference Between 'Desistance' and 'Resilience': Exploring the Relationship Between Two Key Concepts, Youth Justice, 2011, 11(3), s. 224.

${ }^{62}$ P.C. Giordano, S.A. Cernkovich, J.L. Rudolph, Gender, Crime, and Desistance, s. 1026. 
Z punktu widzenia implikacji tego zagadnienia dla działalności resocjalizacyjnej, istotny wydaje się podejmowany przez wielu autorów ${ }^{63}$ temat czasowego lub przyczynowego porządku pomiędzy procesami kognitywnymi, okolicznościami sytuacyjnymi i zaniechaniem działalności przestępczej. Jak zauważają L. Kazemian i S. Maruna, jest to „drażliwy problem metodologiczny", głównie dlatego, że zmiany sytuacyjne i kognitywne są często wzajemnie powiązane i mogą występować jednocześnie ${ }^{64}$. M. Le Blanc podsumował tę ideę, twierdząc, że niektóre potencjalne zmienne mogą występować $\mathrm{w}$ tak znacznej bliskości od zaniechania, że pomimo wszelkich starań niemożliwe staje się zmierzenie, co pojawia się jako pierwsze, co więcej - mogą one wywierać na siebie wzajemny wpływ. Jako przykład autor ten podaje przestępczość młodocianych, która może wynikać ze słabych więzi z rodzicami, ale też sama je osłabiać ${ }^{5}$. Ponadto, nie tylko interakcja pomiędzy czynnikami społecznymi a subiektywnymi jest dynamiczna, różnorodna, złożona i niejednokrotnie trudna do przewidzenia, ale również różne czynniki mogą mieć odmienne znaczenie dla zmiany na różnym etapie rozwojowym.

$\mathrm{W}$ tym kontekście równie istotnym zagadnieniem podkreślanym w literaturze jest kwestia samoselekcji (self-selection) i sekwencyjności (sequencing) ${ }^{66}$. Ponieważ punkty zwrotne i wydarzenia życiowe (zawarcie małżeństwa, podjęcie pracy) nie są losowo przypisywane osobom, trudno ocenić, czy te zjawiska są przyczynami czy korelatami procesu resocjalizacji.

Podobnie jak dzieci z neuropsychologicznymi i innymi deficytami temperamentu nie są losowo przypisane wspierającemu lub niewspierającemu środowisku, wydarzenia życiowe mogą nie być przypadkowe; mogą nastąpić na skutek procesu samoselekcji i odzwierciedlać skłonności przestępcze ${ }^{67}$.

Lepsze zrozumienie złożonych relacji pomiędzy społecznymi i subiektywnymi zmianami towarzyszącymi procesowi resocjalizacji jest nie tylko kluczowym problemem $\mathrm{w}$ badaniach nad tym zjawiskiem, ale ma również daleko idące implikacje dla wspomagania tego procesu czy, szerzej, praktyki oddziaływań. Na przykład, jeżeli zmiany społeczne poprzedzają zmiany

${ }^{63}$ A. Bottoms et al., Towards Desistance: Theoretical Underpinnings for an Empirical Study, The Howard Journal of Criminal Justice, 2004, 43(4), s. 368-389 i cytowana tam literatura.

${ }^{64}$ L. Kazemian, S. Maruna, Desistance from Crime, [w:] Handbook on Crime and Deviance, red. M.D. Krohn, A.J. Lizotte, G.P. Hall, Springer 2009, s. 288.

${ }_{65}$ M. Le Blanc, Late Adolescence Deceleration of Criminal Activity and Development of Self, and Social Control, Studies on Crime and Crime Prevention, 1993, 2, s. 56, za: L. Kazemian, Desistance from Crime: Theoretical, Empirical, Methodological, and Policy Considerations, Journal of Contemporary Criminal Justice, 2007, 23(1), s. 14.

${ }^{66}$ L. Kazemian, D.P. Farrington, The Developmental Evidence Base: Desistance, [w:] Forensic Psychology, red. G.J. Towl, D.A. Crighton, Oxford 2010, s. 139 i cytowana tam literatura.

67 Tamże. 
w motywacji i prowadzą do nich, tworzenie różnego rodzaju programów, doradztwa czy terapii, które miałyby się odnosić do jej rozwoju już w trakcie odbywania kary pozbawienia wolności, będą miały minimalną, jeśli nie zerową, wartość.

Na zakończenie rozważań nad relacjami między czynnikami wewnętrznymi i zewnętrznymi w procesie odstąpienia od przestępczości jeszcze raz należy podkreślić, że poszukiwanie możliwości zidentyfikowania sekwencji wpływów poznawczych i zewnętrznych jest na równi niemożliwe, co pozbawione sensu, gdyż operują one poprzez dynamiczne i interakcyjne procesy. W literaturze podnosi się potrzebę rozróżnienia pomiędzy tymczasowymi czynnikami subiektywnymi (nastrój, myśli, interpretacje) a względnie bardziej trwałymi i stałymi zmiennymi poznawczymi (jak np. osobista tożsamość, autonarracja). To właśnie te bardziej trwałe, społeczno-poznawcze charakterystyki poddane analizie dostarczają wglądu w między - i wewnątrzjednostkowe różnice w odpowiedzi na ten sam zbiór okoliczności i pogłębiają rozumienie czynników subiektywnych towarzyszących trwałości odstąpienia oraz przestępczości ${ }^{68}$.

\section{BIBLIOGRAFIA}

Adams K., Developmental Aspects of Adult Crime, [w:] Advances in Criminological Theory, vol. 6: Developmental Theories of Crime and Delinquency, red. T.P. Thornberry, New Brunswick 1997.

Bottoms A. et al., Towards Desistance: Theoretical Underpinnings for an Empirical Study, The Howard Journal of Criminal Justice, 2004, 43(4).

Bottoms A., Shapland J., Steps towards desistance among male young adult recidivists, [w:] Escape Routes: Contemporary Perspectives on Life after Punishment, red. S. Farrall, M. Hough, S. Maruna, R. Sparks, Abingdon 2011.

Brzezińska A., Społeczna psychologia rozwoju, Warszawa 2000.

Brzezińska A., Dzieciństwo i dorastanie: korzenie tożsamości osobistej i społecznej, [w:] Edukacja regionalna, red. A. Brzezińska, A. Hulewska, J. Słomska, Warszawa 2006.

Carlsson Ch., Processes of Intermittency in Criminal Careers: Notes from a Swedish Study on Life Courses and Crime, International Journal of Offender Therapy and Comparative Criminology, 2013, 57(8).

Caspin A., Moffit T.E., The Continuity of Maladaptive Behavior: From Description to Understanding in the Study of Antisocial Behavior, [w:] Developmental Psycholopathology, vol. 2: Risk, disorder and adaptation, red. D. Cicchetti, D.J. Cohen, New York 1995.

Farrall S., Bottoms A., Shapland J., Social Structures and Desistance from Crime, European Journal of Criminology, 2010, 7(6).

Farrall S., Bowling B., Structuration, Human Development and Desistance from Crime, British Journal of Criminology, 1999, 39(2).

${ }^{68}$ T.P. LeBel et al., The 'Chicken and Egg', s. 153. 
Farrall S., Calverley A., Understanding Desistance from Crime: Emerging Theoretical Directions in Resettlement and Rehabilitation, New York 2006.

Farrington D.P., West D.J., Effects of Marriage, Separation, and Children on Offending by Adults Males, [w:] Current Perspectives on Aging and the Life Cycle, red. Z.S. Blau, J. Hagan, vol. 4, Greenwich Conn. 1995.

Fitzpatrick C., What is Difference Between 'Desistance' and 'Resilience': Exploring the Relationship Between Two Key Concepts, Youth Justice, 2011, 11(3).

Giddens A., Stanowienie społeczeństwa. Zarys teorii strukturacji, Poznań 2003.

Giordano P.C., Cernkovich S.A, Rudolph J.L., Gender, Crime, and Desistance: Toward a Theory of Cognitive Transformation, American Journal of Sociology, 2002, 107(4).

Gottfredson M.R., Hirschi T., A General Theory of Crime, Stanford 1990.

Kazemian L., Desistance from Crime: Theoretical, Empirical, Methodological, and Policy Considerations, Journal of Contemporary Criminal Justice, 2007, 23(1).

Kazemian L., Farrington D.P., The Developmental Evidence Base: Desistance, [w:] Forensic Psychology, red. G.J. Towl, D.A. Crighton, Oxford 2010.

Kazemian L., Maruna S., Desistance from Crime, [w:] Handbook on Crime and Deviance, red. M.D. Krohn, A.J. Lizotte, G.P. Hall, Springer 2009.

Laub J.H., Sampson R.J., Understanding Desistance from Crime, Crime and Justice, 2001, 28.

Laub J.H., Sampson R.J., Shared Beginnings, Divergent Lives: Delinquent Boys to Age 70, Cambridge - Massachusetts - London 2003.

LeBel T.P. et al., The 'Chicken and Egg' of Subjective and Social Factors in Desistance from Crime, European Journal of Criminology, 2008, 5(2).

Le Blanc M., Late Adolescence Deceleration of Criminal Activity and Development of Self, and Social Control, Studies on Crime and Crime Prevention, 1993, 2.

Loeber R. et al., Initiation, Escalation and Desistance in Juvenile Offending and Their Correlates, Journal of Criminal Law and Criminology, 1991, 82(1).

Maruna S., Desistance and Development: The Psychosocial Process of 'Going Straight', The British Criminology Conferences: Selected Proceedings, vol. 2. Papers from the British Criminology Conference, Queens University, Belfast, 15-19 July 1997, http:/ / britsoccrim.org/volume2/003.pdf, [dostęp: 26.07.2014].

Maruna S., Making Good: How Ex-Convicts Reform and Rebuild Their Lives, Washington 2001.

McNeill F., Weaver B., Changing Lives? Desistance Research and Offender Management, The Scottish Centre for Crime and Justice Research, Report No.03/2010,

Murray C., Conceptualizing Young People's Strategies of Resistance to Offending as 'Active Resilience', British Journal of Social Work, 2010, 40(1).

Muskała M., Skazani na brak sukcesu? Reprodukcja wykluczenia społecznego w świetle koncepcji Pierre'a Bourdieu, [w:] Młodzież i sukces życiowy, red. D. Hildebrandt-Wypych, K. Kabacińska, Kraków 2010.

Muskała M., „Odstapienie od przestępczości” w teorii i praktyce resocjalizacyjnej, Poznań 2016.

Pilecka W., Fryt J., Teoria dziecięcej odporności psychicznej, [w:] Psychologia zdrowia dzieci i młodzieży. Perspektywa kliniczna, red. W. Pilecka, Kraków 2011.

Robertson L. et al., Promoting Desistance and Resilience in Young People Who Offend, The Scottish Journal of Crime and Justice Studies, 2006, 12.

Rumgay J., Scripts for Safer Survival: Pathways Out of Female Crime, The Howard Journal of Criminal Justice, 2004, vol. 43(4).

Sampson R.J., Laub J.H., Desistance from Crime over the Life Course, [w:] Desistance from Crime over the Life Course, red. J. Mortimer, M.J. Shanahan, Springer 2004.

Savolainen J., Work, Family and Criminal Desistance: Adult Social Bonds in a Nordic Welfare State, British Journal of Criminology, 2009, 49(3). 
Uggen C., Work as a Turning Point in the Life Course of Criminals: A Duration Model of Age, Employment, and Recidivism, American Sociological Review, 2000, 65(1).

Urban B., Zaburzenia w zachowaniu i przestępczość młodzieży, Kraków 2000.

Urban B., Kognitywno-interakcyjne podstawy wspótczesnej resocjalizacji, [w:] Resocjalizacja, ciągłość i zmiana, red. M. Konopczyński, B. Nowak, Warszawa 2008.

Urban B., Agresja młodzieży i odrzucenie rówieśnicze, Warszawa 2012.

Walker K.G., Bowen E., Brown S., Examining the Psychological, Social and Subjective Dimensions Associated with Desistance from Offending: A Review of the Literature, 2011, http:/ / works.bepress.com/kate_walker/1, [dostęp: 26.07.2014].

Wojciechowska J., Okres wczesnej dorostości. Jak rozpoznać ryzyko i jak pomagać? [w:] Psychologiczne portrety człowieka. Praktyczna psychologia rozwojowa, red. A.I. Brzezińska, Gdańsk 2005. 